Journal of Bangladesh Academy of Sciences, Vol. 38, No. 1, 61-69, 2014

\title{
MICRONUTRIENT AND FUNGICIDES MANAGEMENT PRACTICES TO CONTROL THE ALTERNARIA BLIGHT OF MUSTARD
}

\author{
M.N. HAIDER, M.R. ISLAM, F.M. AMINUZZAMAN, H. MEHRAJ ${ }^{1}$ AND \\ AFM JAMAL UDDIN ${ }^{* 1}$ \\ Department of Plant Pathology, Sher-e-Bangla Agricultural University, Dhaka-1207, \\ Bangladesh
}

\begin{abstract}
Experiments were conducted to evaluate the efficacy of different micronutrients and fungicides against Alternaria brassicae and Alternaria blight on growth and yield contributing attributes of mustard. Among the treatments, $\mathrm{T}_{6}$ showed the highest performance against Alternaria blight in terms of disease incidence. The lowest leaf infection (9.9\%), leaf area diseases $(2.5 \%)$, pod infection $(9.3 \%)$ and number of spots per pod (0.6) were recorded in $\mathrm{T}_{6}$. Highest leaf infection $(56.1 \%)$, diseased leaf area $(18.31 \%)$, pod infection $(42.7 \%)$ and number of spots per pod (1.9) were recorded in control. The highest yield $(1086.0 \mathrm{~kg} / \mathrm{ha})$, germination percentage (99.1) and the lowest seed infection $(6.5 \%)$ of harvested seeds were obtained from the $\mathrm{T}_{6}$, whereas lowest from $\mathrm{T}_{1}$. The performances of micronutrients were better than control but the performances of micronutrients did not differ significantly when it was used in combination with fungicides.
\end{abstract}

Key words: Alternaria blight, Micronutrients, Fungicides, Mustard

\section{INTRODUCTION}

Brassica holds the second position in the world oilseeds in respect of production (FAO 2005). It is the major source of edible oil in Bangladesh and more than 183 thousand metric tons of rape and mustard were produced from total 316.9 thousand hectares of cultivable land in the year 2005-2006 (BBS 2006). Diseases have been identified as one of the major factors. Rapeseed-mustard suffers from about 14 diseases (fungus 9, virus 2, bacteria 1, nematode 1 and parasitic plant 1) in Bangladesh. Among these diseases, leaf blight, downy mildew and the parasitic plant are important (Anon. 2007). Leaf blight caused by Alternaria brassicae is widely distributed and the most serious and devastating disease of rapeseed-mustard. The characteristic symptom is the development of circular spots on leaves and pods with concentric ring. Later on spots coalesce and ultimately the leaves become blighted. The disease may cause $25 \%$ yield reduction at severe condition of infection (Anon. 2002). Gray blight (Alternaria brassicae) causes blight of leaf, pod and stem (Meah et al. 1988) and seed abnormalities

\footnotetext{
* Corresponding author: <jamal4@yahoo.com>.

${ }^{1}$ Department of Horticulture, Sher-e-Bangla Agricultural University, Dhaka-1207, Bangladesh.
} 
(Howlider et al. 1991). All the cultivated B. campestris and B. napus varieties are susceptible to the disease, because average yield loss $30-60 \%$ in Bangladesh (Meah et al. 1988) also adversely affects the seed quality reducing seed size, seed discoloration and reduction in oil contents (Howlider et al. 1991, Kaushik et al. 1984). Seed cleaning before sowing has recently been proved effective in reducing infection of seed-borne pathogens and increasing production of healthy seeds (Hossain and Doullah 1998). Chemicals are being successfully used in controlling the disease (Meah et al. 1988). A good number of fungicides and cultural practices are yet remained untested against this disease. Considering the present situation of the disease in the country, further selection of fungicides against Alternaria blight of mustard is necessary. Micronutrient management like use $\mathrm{Zn}, \mathrm{S}$ and $\mathrm{B}$ could be the good options for the management of Alternaria blight of Mustard.

\section{MATERIALS AND METHODS}

The experiment was conducted at the experimental farm of the Department of Plant Pathology, Sher-e-Bangla Agricultural University, Dhaka, Bangladesh from November 2007 to February, 2008. The experimental field was fertilized with cow-dung @ 1 ton/ha, urea@250 kg/ha, TSP 170 kg/ha, MP 85 kg/ha, gypsum 150 kg/ha, zinc oxide 5 kg/ha and boric acid @10 kg/ha (Mondal et al. 2011). Urea was applied by two installments. Total amount of TSP, MP, gypsum, $\mathrm{ZnO}$ and boric acid along with half of the urea were applied at the time of final land preparation as a basal dose. The second half of the urea was top-dressed at the time of flower initiation. But micronutrients (gypsum, $\mathrm{ZnO}$, boric acid) were applied only in the desired plots which are selected for micronutrient application. Altogether ten different treatments were employed in the experiment and these were $\mathrm{T}_{1}$ : control, $\mathrm{T}_{2}$ : rovral $50 \mathrm{WP}(0.2 \%), \mathrm{T}_{3}$ : ridomil gold MZ-72WP $(0.2 \%), \mathrm{T}_{4}$ : dithane M-45 $(0.3 \%), \mathrm{T}_{5}$ : bavistin $\mathrm{DF}(0.1 \%), \mathrm{T}_{6}$ : rovral $50 \mathrm{WP}(0.2 \%)+$ micronutrients, $\mathrm{T}_{7}$ : ridomil gold MZ-72 WP $(0.2 \%)+$ micronutrients, $\mathrm{T}_{8}$ : dithane $\mathrm{M}-45(0.3 \%)+$ micronutrients; $\mathrm{T}_{9}$ : bavistin $\mathrm{DF}(0.1 \%)+$ micronutrients and $\mathrm{T}_{10}$ : micronutrients (gypsum + zinc oxide + boric acid). The mustard (Brassica campestries) variety SAU Sarisha-1 released from Sher-e-Bangla Agricultural University was used in the experiment. Seeds were collected from Department of Genetics and Plant Breeding. Experiments were laid out in Randomized Complete Block Design (RCBD) with three replications. The whole plot was divided into three blocks each containing ten plots of $2 \mathrm{~m} \times 1.5 \mathrm{~m}$ size, giving 30 units plots. The space between the blocks was $0.75 \mathrm{~m}$ and between the plots $0.5 \mathrm{~m}, 30$ $\mathrm{cm}$ from row to row and $10 \mathrm{~cm}$ from plant to plant were maintained. Seeds were sown in lines in the experimental plots. The seeds were placed at about $1.5 \mathrm{~cm}$ depth in the soil. Seeds were treated by using concerned fungicides with recommended concentration for 
five minutes. The fungicidal solutions were prepared by mixing with required amount of fungicides (rovral 50 WP @ 0.2\%, ridomil gold MZ-72 @ 0.2\%, dithane M-45@0.3\% and bavistin DF @ 0.1\%) with tap water. Spraying was done at 30,40, 50 and 60 days after sowing using freshly prepared solutions. Special attention was given to complete coverage of the growing plants with the fungicides. Adequate precaution was taken to avoid drifting of spray materials from one plot to the neighboring ones.

When $80 \%$ of the plants showed symptoms of maturity i.e. straw colour of siliquae, leaves, stem and desirable seed colour in the matured siliquae, the crop was assessed to attain maturity. At maturity, ten plants were selected at random from all lines in each plot, harvested by uprooting and tagged properly. Data were recorded on different parameters from these harvested plants.

For health test and detecting the incidence of A. brassicae in the harvested mustard seed, 200 seeds randomly drawn from each sample were tested in standard blotter technique (ISTA 2000). In each Petri dish, 25 seeds were placed in equidistance. All plates with seeds were incubated at room temperature $\left(25 \pm 2{ }^{\circ} \mathrm{C}\right)$. After $7-10$ days of incubation, each seed was observed under stereo-binocular microscope to detect the presence of $A$. brassicae, seed germination and infection.

Data were collected from the parameters of leaf infection (\%), per cent leaf area diseased, pod infection (\%), number of spots/pod, number of leaf/plant, number of branches/plant, plant height $(\mathrm{cm})$, number of pods/plant, 1000-seed weight, yield/plant $(\mathrm{gm})$, yield ( $\mathrm{Kg} / \mathrm{ha})$, seed germination $(\%)$, seed infection $(\%)$. Data were statistically analyzed using MSTAT-C computer package program; means were compared by DMRT at the $5 \%$ level.

\section{RESULTS AND DISCUSSION}

Efficacy of fungicides viz. rovral $50 \mathrm{WP}$, dithane M-45, ridomil gold MZ-72 and bavistin DF and micronutrients in controlling Alternaria blight of mustard caused by Alternaria brassicae were assessed.

All the treatments gave significant reduction of leaf infection (\%) of Alternaria blight of mustard (SAU Sarisha-1) at different days after sowing (DAS) (Table 1). Leaf infection (\%) of mustard increased gradually with the advancement of crop growth. At 85 DAS, the highest leaf infection $(56.1 \%)$ was found in control plots and the lowest leaf infection $(9.9 \%)$ was recorded in $\mathrm{T}_{6}$ followed by $\mathrm{T}_{2}(10.6 \%)$ (Fig. 1a). There was no significant difference between the applications of fungicides alone or in combination with micronutrients but application of micronutrients alone showed significantly better performance compared to control. 

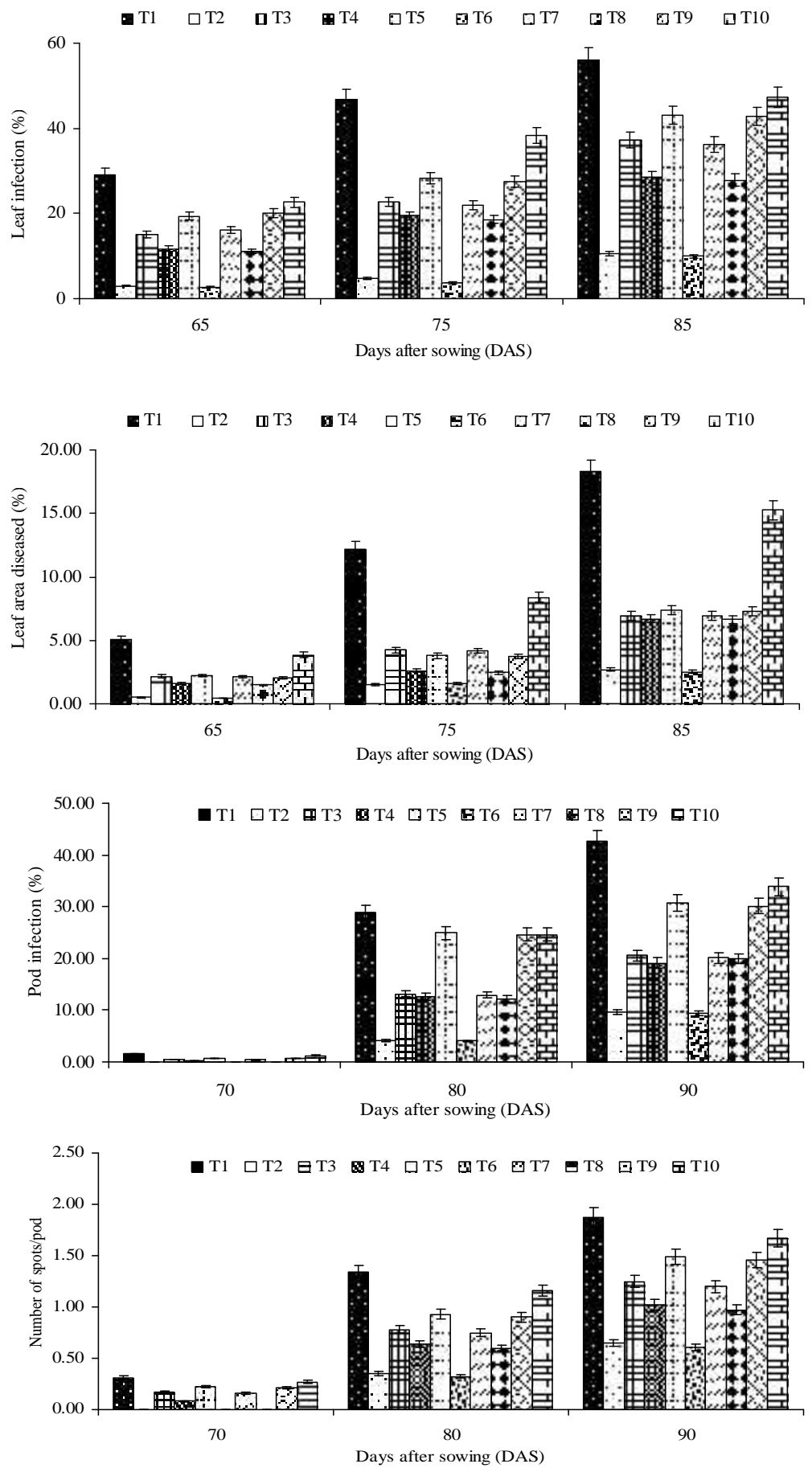

Fig. 1. Effects of different treatments on (a) leaf infection, (b) leaf area diseased, (c) pod infection and (d) on number of spots/pod of mustard at different days after sowing (DAS). 
Leaf area diseased (\%) of SAU Sarisha-1 varied significantly at different DAS in response to the application of different treatments. Leaf area diseased (\%) of mustard increased gradually with the advancement of crop growth. At 85 DAS highest leaf area diseased (18.3\%) was found in $\mathrm{T}_{1}$ while lowest $(2.5 \%)$ from $\mathrm{T}_{6}$ followed by $\mathrm{T}_{2}(2.7 \%)$ (Fig. 1b). The result showed that application of rovral $50 \mathrm{WP}$ alone caused $85.41 \%$ reduction of LAD while rovral 50 WP combined with micronutrients caused $86.2 \%$ reduction of LAD (Table 1).

Pod infection (\%) of mustard increased gradually with the increase of crop age. At 90 DAS, highest pod infection (42.7\%) was obtained from $\mathrm{T}_{1}$ whereas lowest $(9.3 \%)$ from $\mathrm{T}_{6}$. The least effective treatment to reduce pod infection was $\mathrm{T}_{10}(33.9 \%)$ (Fig. 1c). $\mathrm{T}_{6}$ reduced $78.2 \%$ pod infection over control followed by $\mathrm{T}_{2}(77.6 \%$, Table 1$)$.

Number of spots per pod varied significantly with different treatments at different DAS. At 90 DAS, maximum of 1.9 spots per pod was recorded in $\mathrm{T}_{1}$ while minimum (0.6) from $\mathrm{T}_{6}$ followed by $\mathrm{T}_{2}$ (0.7) (Fig. 1d). Maximum reduction of number of spots/pod (67.4\%) over control at 90 DAS was obtained from $\mathrm{T}_{6}$ followed by $\mathrm{T}_{2}(65.2 \%)$ whereas minimum from $\mathrm{T}_{10}(10.7 \%$, Table 1$)$.

Table 1. Effects of different treatments on per cent disease inhibition of mustard recorded at different days after sowing (DAS) ${ }^{*}$.

\begin{tabular}{|c|c|c|c|c|c|c|c|c|}
\hline \multirow{2}{*}{$\begin{array}{c}\text { Treatments } \\
\mathrm{T}_{1}\end{array}$} & \multicolumn{2}{|c|}{$\begin{array}{l}\% \text { inhibition of leaf } \\
\text { infection over control } \\
\text { at } 85 \text { DAS }\end{array}$} & \multicolumn{2}{|c|}{$\begin{array}{l}\% \text { inhibition of } \\
\text { LAD over control } \\
\text { at } 85 \text { DAS }\end{array}$} & \multicolumn{2}{|c|}{$\begin{array}{c}\% \text { inhibition of pod } \\
\text { infection over control } \\
\text { at } 90 \text { DAS }\end{array}$} & \multicolumn{2}{|c|}{$\begin{array}{c}\% \text { reduction of } \\
\text { number of spots/pod } \\
\text { over control at } 90 \\
\text { DAS }\end{array}$} \\
\hline & 0.0 & $\mathrm{i}$ & 0.0 & $\mathrm{~g}$ & 0.0 & e & 0.0 & $\mathrm{j}$ \\
\hline $\mathrm{T}_{2}$ & 81.2 & $b$ & 85.4 & $\mathrm{~b}$ & 77.6 & $\mathrm{a}$ & 65.2 & $\mathrm{~b}$ \\
\hline $\mathrm{T}_{3}$ & 33.8 & $f$ & 62.0 & $\mathrm{~d}$ & 51.8 & $\mathrm{~b}$ & 33.2 & $\mathrm{f}$ \\
\hline $\mathrm{T}_{4}$ & 49.2 & d & 63.4 & $\mathrm{c}$ & 55.2 & $\mathrm{~b}$ & 45.5 & d \\
\hline $\mathrm{T}_{5}$ & 23.2 & g & 59.8 & e & 28.1 & $\mathrm{~cd}$ & 20.3 & $\mathrm{~h}$ \\
\hline $\mathrm{T}_{6}$ & 82.3 & $\mathrm{a}$ & 86.2 & $\mathrm{a}$ & 78.2 & $\mathrm{a}$ & 67.4 & $\mathrm{a}$ \\
\hline $\mathrm{T}_{7}$ & 35.4 & $\mathrm{e}$ & 62.3 & d & 52.8 & $\mathrm{~b}$ & 35.8 & $\mathrm{e}$ \\
\hline $\mathrm{T}_{8}$ & 50.4 & $\mathrm{c}$ & 63.8 & $\mathrm{c}$ & 53.2 & $\mathrm{~b}$ & 48.1 & $\mathrm{c}$ \\
\hline $\mathrm{T}_{9}$ & 23.7 & $\mathrm{~g}$ & 60.0 & $\mathrm{e}$ & 29.5 & $\mathrm{c}$ & 21.9 & $\mathrm{~g}$ \\
\hline $\mathrm{T}_{10}$ & 15.7 & $\mathrm{~h}$ & 16.6 & $\mathrm{f}$ & 20.7 & $\mathrm{~d}$ & 10.7 & i \\
\hline CV (\%) & 0.5 & & 0.5 & & 7.7 & & 0.5 & \\
\hline $\mathrm{S}$ & 0.8 & & 0.6 & & 10.5 & & 0.9 & \\
\hline
\end{tabular}

*In a column means having same letter (s) denote no significant difference at $5 \%$ level.

Plant height varied significantly among the different treatments. Tallest plant was obtained from $\mathrm{T}_{6}(103.3 \mathrm{~cm})$ which was statistically identical with $\mathrm{T}_{8}(102.5 \mathrm{~cm})$, whereas shortest plant $(85.71 \mathrm{~cm})$ was recorded $\mathrm{T}_{1}$ (Table 2). 
Significant variation was found among the treatments in terms of number of branches/plant. Maximum number of branches/plant (5.1) was found in $\mathrm{T}_{6}$ whereas $\mathrm{T}_{1}$ produced lowest number of branches per plant (4.1) (Table 2).

Seeds obtained from $\mathrm{T}_{6}$ (rovral + micronutrients) showed the maximum germination $(99.1 \%)$ whereas seed from $\mathrm{T}_{1}$ showed minimum germination $(82.2 \%)$ (Table 2 ).

Table 2. Effects of different treatments on growth, yield and yield contributing characters of mustard".

\begin{tabular}{ccccccccccc}
\hline Treatments & \multicolumn{2}{c}{$\begin{array}{c}\text { Branches/ } \\
\text { plant }\end{array}$} & \multicolumn{2}{c}{$\begin{array}{c}\text { Plant height } \\
(\mathrm{cm})\end{array}$} & $\begin{array}{c}\text { \% yield increased } \\
\text { over control }\end{array}$ & \multicolumn{2}{c}{$\begin{array}{c}\text { Germination } \\
\%\end{array}$} & \multicolumn{2}{c}{$\begin{array}{c}\text { Seed infection } \\
\%\end{array}$} \\
\hline $\mathrm{T}_{1}$ & 4.1 & $\mathrm{c}$ & 85.7 & $\mathrm{c}$ & 0.0 & $\mathrm{j}$ & 82.2 & $\mathrm{j}$ & 18.3 & $\mathrm{a}$ \\
$\mathrm{T}_{2}$ & 4.8 & $\mathrm{abc}$ & 91.8 & $\mathrm{bc}$ & 38.9 & $\mathrm{~b}$ & 98.9 & $\mathrm{~b}$ & 6.5 & $\mathrm{~h}$ \\
$\mathrm{~T}_{3}$ & 4.6 & $\mathrm{abc}$ & 87.9 & $\mathrm{bc}$ & 25.3 & $\mathrm{f}$ & 91.5 & $\mathrm{f}$ & 14.3 & $\mathrm{e}$ \\
$\mathrm{T}_{4}$ & 4.7 & $\mathrm{abc}$ & 91.2 & $\mathrm{bc}$ & 28.8 & $\mathrm{~d}$ & 95.8 & $\mathrm{~d}$ & 11.9 & $\mathrm{~g}$ \\
$\mathrm{~T}_{5}$ & 4.5 & $\mathrm{abc}$ & 87.8 & $\mathrm{bc}$ & 14.0 & $\mathrm{i}$ & 88.5 & $\mathrm{~h}$ & 15.4 & $\mathrm{c}$ \\
$\mathrm{T}_{6}$ & 5.1 & $\mathrm{a}$ & 103.3 & $\mathrm{a}$ & 39.8 & $\mathrm{a}$ & 99.1 & $\mathrm{a}$ & 6.3 & $\mathrm{i}$ \\
$\mathrm{T}_{7}$ & 5.0 & $\mathrm{ab}$ & 95.7 & $\mathrm{ab}$ & 26.9 & $\mathrm{e}$ & 91.9 & $\mathrm{e}$ & 14.2 & $\mathrm{f}$ \\
$\mathrm{T}_{8}$ & 5.1 & $\mathrm{ab}$ & 102.5 & $\mathrm{a}$ & 30.2 & $\mathrm{c}$ & 98.1 & $\mathrm{c}$ & 11.9 & $\mathrm{~g}$ \\
$\mathrm{~T}_{9}$ & 4.9 & $\mathrm{ab}$ & 96.2 & $\mathrm{ab}$ & 17.8 & $\mathrm{~g}$ & 88.8 & $\mathrm{~g}$ & 15.3 & $\mathrm{~d}$ \\
$\mathrm{~T}_{10}$ & 4.4 & $\mathrm{bc}$ & 90.9 & $\mathrm{bc}$ & 14.9 & $\mathrm{~h}$ & 84.3 & $\mathrm{i}$ & 17.8 & $\mathrm{~b}$ \\
$\mathrm{CV}(\%)$ & 7.7 & & 5.3 & & 0.5 & & 0.002 & & 0.002 & \\
$\mathrm{~S}$ & 0.2 & & 2.8 & & 1.3 & & 0.1 & & 0.1 & \\
\hline
\end{tabular}

*In a column means having same letter (s) denote no significant difference at 5\% level.

Different level of seed infection (\%) by Alternaria brassicae of harvested seeds obtained from treated plots with different fungicides and micronutrients was found. Lower seed infection was found in seeds from treated plot compared to control, except seeds collected from micronutrient treated plots. Seeds from $\mathrm{T}_{1}$ showed highest seed infection (18.3\%) while lowest from $\mathrm{T}_{6}(6.5 \%)$ (Table 2$)$.

Table 3. Effect of different treatments on growth, yield and yield contributing characters of mustard*.

\begin{tabular}{|c|c|c|c|c|c|c|c|c|c|c|}
\hline \multirow{3}{*}{$\begin{array}{c}\text { Treatments } \\
\mathrm{T}_{1}\end{array}$} & \multirow{2}{*}{\multicolumn{2}{|c|}{$\begin{array}{c}\text { No of leaf/ } \\
\text { plant }\end{array}$}} & \multicolumn{8}{|c|}{ Yield and yield contributing characters } \\
\hline & & & \multicolumn{2}{|c|}{ No of pods/plant } & \multicolumn{2}{|c|}{1000 -seed weight $(\mathrm{g})$} & \multicolumn{2}{|c|}{ Yield/plant (g) } & \multicolumn{2}{|c|}{ Yield kg/ha } \\
\hline & 6.3 & $\mathrm{e}$ & 35.8 & $\mathrm{e}$ & 2.9 & $\mathrm{f}$ & 2.5 & $\mathrm{e}$ & 654.2 & $\mathrm{j}$ \\
\hline $\mathrm{T}_{2}$ & 8.4 & $\mathrm{ab}$ & 44.7 & $\mathrm{~b}$ & 3.6 & $a b$ & 4.0 & $\mathrm{a}$ & 1071.0 & $\mathrm{~b}$ \\
\hline $\mathrm{T}_{3}$ & 7.2 & $\mathrm{~cd}$ & 38.9 & de & 3.2 & cde & 3.3 & bc & 875.6 & $\mathrm{f}$ \\
\hline $\mathrm{T}_{4}$ & 7.6 & $\mathrm{bc}$ & 40.5 & $\mathrm{~cd}$ & 3.3 & bc & 3.4 & $\mathrm{~b}$ & 918.7 & $\mathrm{~d}$ \\
\hline $\mathrm{T}_{5}$ & 6.7 & cde & 37.2 & $\mathrm{e}$ & 2.9 & ef & 2.9 & $\mathrm{~d}$ & 761.0 & i \\
\hline $\mathrm{T}_{6}$ & 8.6 & $\mathrm{a}$ & 47.3 & $\mathrm{a}$ & 3.7 & $a b$ & 4.1 & $\mathrm{a}$ & 1086.0 & $\mathrm{a}$ \\
\hline $\mathrm{T}_{7}$ & 7.6 & $\mathrm{bc}$ & 41.4 & $\mathrm{~cd}$ & 3.2 & cde & 3.4 & $\mathrm{bc}$ & 894.6 & e \\
\hline $\mathrm{T}_{8}$ & 8.3 & $a b$ & 43.8 & $\mathrm{bc}$ & 3.4 & $a b c$ & 3.5 & $\mathrm{~b}$ & 937.3 & $\mathrm{c}$ \\
\hline $\mathrm{T}_{9}$ & 7.1 & $\mathrm{~cd}$ & 40.6 & $\mathrm{~cd}$ & 3.0 & def & 3.0 & $\mathrm{~cd}$ & 795.8 & g \\
\hline $\mathrm{T}_{10}$ & 6.7 & $\mathrm{de}$ & 38.4 & de & 3.0 & def & 2.9 & $\mathrm{~d}$ & 769.1 & $\mathrm{~g}$ \\
\hline CV (\%) & 6.3 & & 3.8 & & 4.8 & & 6.4 & & 6.3 & \\
\hline $\mathrm{S}$ & 0.3 & & 0.9 & & 0.1 & & 0.1 & & 0.002 & \\
\hline
\end{tabular}

*In a column means having same letter (s) denote no significant difference at 5\% level 
Number of leaves per plant varied significantly due to the application of different treatments. The highest number of leaves per plant (8.6) was recorded from $\mathrm{T}_{6}$ while lowest (6.3) from $\mathrm{T}_{1}$ (Table 3). Number of pods/plant differed significantly among the treatments. The highest number of pod/plant (47.3) was recorded from $\mathrm{T}_{6}$ whereas minimum from $\mathrm{T}_{1}$ (35.8) (Table 3). Significant variation was found among the treatments in terms of 1000 -seed weight. Spraying with rovral + micronutrients $\left(\mathrm{T}_{6}\right)$ produced the maximum 1000-seed weight (3.7g) while minimum (2.9g) from $\mathrm{T}_{1}$ (Table 3). Yield/plant (g) and calculated yield/hectare $(\mathrm{kg})$ significantly differed among the treatments. Maximum yield/plant $(4.1 \mathrm{~g})$ and calculated yield/ha $\left(1086.00 \mathrm{~kg}\right.$ ) was obtained from $\mathrm{T}_{6}$ which was statistically identical with $\mathrm{T}_{2}$, whereas minimum from $\mathrm{T}_{1}$ (yield/plant: $2.5 \mathrm{~g}$ and yield/hectare: $654.2 \mathrm{~kg}$ ) (Table 3).

Application of fungicides either alone or in combination with micronutrients had significant effect in reducing the disease incidence and severity with increasing seed yield. Seed treatment by foliar spraying with rovral in combination with soil application of micronutrients inhibited the leaf infection by $82.3 \%$ over control. Similar trend of results were observed in case of reducing pod infection due to the application of different treatments. In case of diseased leaf area (\%), the application of rovral in combination with micronutrients that reduced $86.2 \%$ LAD compared to control. It was observed that leaf infection (\%) and leaf area diseased (\%) increased gradually with the advancement of crop growth but the rate of increasing varied significantly in response of the treatment application. The effect of treatments on yield contributing characters like number of leaves per plant, number of branches per plant, plant height and 1000-seed weight was remarkably influenced by increasing seed yield. Highest seed yield (4.1 g/plant; calculated yield $1086.0 \mathrm{~kg} / \mathrm{ha}$ ) was obtained from Rovral $50 \mathrm{WP}+$ micronutrients treated plot against the disease that increased seed yield by $39.8 \%$ compared to control. Statistically similar yield was obtained from Rovral alone treated plot $(1071.0 \mathrm{Kg} / \mathrm{ha})$ that increased seed yield by $38.9 \%$ and $30.2 \%$, respectively. Alam (2007) while working with fungicides and plant extracts against the Alternaria blight of mustard caused by Alternaria brassicae and Alternaria brassicicola, reported that Rovral 50 WP (0.2\%) was the potential fungicide in controlling disease incidence and severity and increasing seed yield by $48.19 \%$ over control. Rovral 50 WP (iprodione) significantly reduced disease incidence and severity and increased seed yield when applied alone or in combination with other fungicides followed by Dithane M-45 (Hossain and Mian 2006). Foliar application of Rovral significantly reduced the seed borne infection of Alternaria spp. and increased germination percentage of mustard seed (Anon. 1992). It was reported that seed-born infection of Alternaria spp. was reduced above $90 \%$ and seed germination was increased above $9.00 \%$ over the control while seed infection was reduced up to $18.80 \%$ with three times foliar application of rovral. 
Foliar application of mancozeb $(0.2 \%)$ at 15 days interval resulted in the lowest incidence of Alternaria blight and the highest seed yield providing cost benefit ratio 1 : 5.2 (Singh and Singh 2005) and Rovral at 1\% concentration given at 7 days interval remarkably reduced Alternaria blight intensity increasing seed yield (Ferdous et al. 2002). Mukherjee et al. (2003) studied the efficacy of iprodione against Alternaria blight and found it more effective than mancozeb. It reduced the disease incidence and increased mustard yield by $59 \%$ over the control. The lowest seed infection $(6.50 \%)$ by Alternaria brassicae was found in the seed lot obtained from treated plot with Rovral 50 $\mathrm{WP}+$ micronutrients compared to control. Seeds obtained from rovral + micronutrientstreated plots showed the maximum germination (99.10\%). Seeds obtained from control plots showed the minimum germination $(82.17 \%)$. The present findings corroborate with the findings of previous research report (Hossain and Mian 2006), evaluated 6 fungicides alone or in combination in a field trial and reported that seed infection with Alternaria spp. was significantly lower in seeds obtained from Rovral and Dithane M-45-treated plots and increased more than $90 \%$ germination of seed.

\section{REFERENCES}

Alam, K.H.H. 2007. Management of gray blight of mustard through some selected treatments. MS Thesis, Dept. of Plant Pathology, Sher-e-Bangla Agricultural University, Dhaka. pp. 21-45.

Anonymous. 1992. Annual Report (1991-92). Plant pathology division, Bangladesh Agricultural Research Institute, Joydebpur. pp. 55-58.

Anonymous. 2007. Oilseed crop diseases and control. Oilseed Research Center (ORC), Bangladesh Agricultural Research Institute (BARI), Joydebpur. pp. 7.

BBS. 2006. Statistical Year Book of Bangladesh. Bangladesh Bureau of Statistics. Statistic Division, Ministry of Planning, Govt. of the People's Republic of Bangladesh. pp. 151.

FAO. 2005. Production Year Book, Food and Agricultural Organization of United Nations, Rome 00108, Italy. 57: 115-133.

Ferdous, S.M., M.B. Meah and M.M. Hossain. 2002. Comparative effect of plant extracts and fungicide on the incidence of Alternaria blight of mustard. Bangladesh J. Training Dev. 15(12): 207-210.

Hossain, M. and A.M. Doullah. 1998. Report on pilot project research of the Seed Pathology Laboratory BAU, paper presented at the DGISP workshop II "Future Strategies for Research, Training and Development of Seed Pathology in Bangladesh" held on December, 1998 at BARC, Dhaka, Bangladesh.

Hossain, M.S. and I.H. Mian. 2006. Efficacy of fungicides for controlling Alternaria blight of cabbage seed crop. Bangladesh J. Agril. Res. 31(2): 189-198.

Howlider, M.A.R., M.B. Meah, M.J. Uddin and A. Rahman. 1991. Effect of fungicides on Alternaria blight, yield and seed quality of mustard. Bangladesh J. Agril. Sci. 18(1): 127-132.

ISTA. 2000. International Rule of Seed Testing Association. Proc. Int. Seed Test Assoc. pp. 180. 
Kaushik. C.D., G.S. Saharan and T.C. Koushik. 1984. Magnitude of loss in yield and management of Alternaria blight in rapeseed-mustard. Ind. Phytopath. 37: 398.

Meah, M.B., M.A.R. Howlidar, M.J. Uddin and A. Rahman. 1988. Effect of fungicide spray at different time and frequencies on Alternaria blight of mustard. Thai. J. Agric. Sci. 21:101-107.

Mondal, M.R.I., M.S. Islam, M.A.B. Jalil, M.M Rahman, M.S. Alam and M.H.H. Rahman. 2011. Krishi Projukti Hatboi (Handbook of Agro-technology), $5^{\text {th }}$ edition. Bangladesh Agricultural Research Institute, Gazipur-1701, Bangladesh, pp. 200.

Mukherjee, I., M. Gopal and S.C. Chatterjee. 2003. Persistence and effectiveness of iprodione against Alternaria blight in mustard. Bulletin Environ. Contamin. Toxico. 70(3): 586-591.

Singh, R.B. and R.N. Singh. 2005. Fungicidal management of foliar diseases of mustard in mideastern India. Ind. Phytopath. 58(1): 51-56.

(Received revised manuscript on 9 December, 2014) 